\section{Portuguese role in spread of HTLV-I virus}

SIR-Having arrived in Tokyo recently, I thought that I had learnt another word to improve my Japanese vocabulary, by reading Gallo et al. ${ }^{1}$ on the origins of human T-lymphotropic viruses. However, the word amakawa, which they inform us is the Japanese word for monkey, is absent in recent reference sources ${ }^{2}$ I have checked. Even my Japanese colleagues in the laboratory seem unaware of it as an alternative term for monkey. The popular word for the Japanese macaque monkey is saru. The monkey deity in Japanese mythology is known as sarutahiko, while a monkey show, once a common street entertainment, is termed sarumawashi ${ }^{3}$.

Rosenior's comment, "the presence of the HTLV-I virus in the vast expanse of continental Asia cannot be ruled out due to lack of epidemiological studies in the area" , seems to have an element of truth, if we believe the historical records of the seafaring adventures of the Portuguese. Figure 1 of Wong-Staal and Gallo ${ }^{5}$ neglects (or slightly distorts) the travel routes taken by the Portuguese in the early part of the sixteenth century. Vasco da Gama landed in Calicut, South India in $1498^{6}$ and, in 1505, a Portuguese fleet commanded by Lourenco de Almeida was blown into Colombo, Ceylon, by adverse winds ${ }^{7}$. Malacca fell to the Portuguese in 1511. It was only after establishing contacts in India, Ceylon and Malacca that the Portuguese arrived in Japan, in 1543.

Prior to his arrival in Japan in 1549, Saint Francis Xavier first disembarked in Goa, India, the centre of Portuguese activity in the East in 1542 and spent the next three years on the southeastern coast of India among the Tamil-speaking pearl fishermen, the Paravas ${ }^{8}$.

According to Percival Spear ${ }^{6}$, in those times the Portuguese relied greatly on sea power based on fortified posts and backed by settlements; however, Portugal, with less than one million people, was desperately short of manpower. Therefore, intermarriage was encouraged between the Portuguese seafaring adventurers and the natives of the Indian subcontinent. That practice was the origin of the mixed population of Luso-Indians (or Goanese) along the western coast of India and in Ceylon.

If it is believed (as mentioned by Gallo et al. ${ }^{\prime}$ ) that the Portuguese came to Japan with monkeys, it is highly probable that the monkeys would have been from the Malayan region and not from Africa. (South-East Asia is also the endemic zone of apes such as gibbon, siamang and orang utan.) Historical records reveal that Portuguese trade was directed mainly between Japan and China rather than Africa.

Therefore, it is my hypothesis that the dark-skinned people who were taken to Japan by Portuguese were the South Indian Tamils of fishermen caste, and not Africans, as suggested by Gallo et al. The linguistic relationship between the Tamil language and Japanese language has been studied by Ohno'.

SACHI SRI Kantha

Laboratory of Marine Biochemistry,

University of Tokyo,

Bunkyo-ku,

Tokyo 113, Japan

1. Gallo, R.C. et al. Nature 320, 219 (1986)

2. Imaizumi, Y. Kodansha Encyclopedia of Japan Vol. 5, 245 (Kodansha, Tokyo, 1983).

3. Saneyoshi, T. Kodansha Encyclopedia of Japan Vol. 5, 245 (Kodansha International Ltd, Tokyo, 1983).

4. Rosenior, J. Nature 318, 100 (1985)

5. Wong-Staal, F. \& Gallo, R.C. Nature 317, 395 (1985)

6. Percival Spear, T.G. Encyclopedia Britannica Vol. 9, 15th edn 392 (Encyclopedia Britannica Inc. Chicago, 1983).

7. Arasaratnam, S. Encyclopedia Britannica Vol. 4, 15th edn 5 (Encyclopedia Britannica Inc. Chicago, 1983)

8. Bireley, R.L. Rev. Encyclopedia Britannica Vol. 19, 15th edn 1055 (Encyclopedia Britannica Inc. Chicago, 1983)

. Ohno, S. Nihongogo to Tamirugo (Shinchosha, Tokyo, 1981).

\section{Commercial samples of subtilisin BPN'}

$\mathrm{S}_{\mathrm{R}}$ - The serine protease subtilisin BPN' (also known as novo or nagarse) from Bacillus amyloliquefaciens has been cloned and expressed on three separate occasions $^{1-3}$. We have found a discrepancy of over a factor of 10 between the activity of the cloned enzyme and the activity of commercial enzyme purchased from Sigma Chemical Company (Protease Type VII, P 5255, from Bacillus amyloliquefaciens). The cloned enzyme has identical activity to an authentic sample of nagarse enzyme which was used for the original crystallographic studies ${ }^{4}$. (This sample was given to A.R.F. by Dr C.S. Wright in 1969.) Kinetic and physical properties indicate that the commercial enzyme is probably subtilisin Carlsberg, isolated from Bacillus licheniformis. We reported our findings to Sigma who have now conducted their own tests. They have just informed us that they agree with our findings and that, for the past ten years, their subtilisin BPN ' has not been the authentic enzyme.

The hydrolysis of the synthetic substrate succinyl-L-alanyl-L-alanyl-L-prolylL-phenylalanyl $p$-nitroanilide by the cloned enzyme is characterized by values for $k_{\text {cat }}$ and $K_{\mathrm{m}}$ of $57 \mathrm{~s}^{-1}$ and $0.15 \mathrm{mM}$ respectively $\left(25^{\circ} \mathrm{C}\right.$ in $0.1 \mathrm{M}$ Tris- $\mathrm{HCl}$ buffer, $p \mathrm{H} \mathrm{8.6)}$, the enzyme concentration being measured by active-site titration. These are identical to the values for the independently cloned gene'. Under the same conditions, the values for the authentic nagarse enzyme are essentially identical at $60 \mathrm{~s}^{-1}$ and $0.15 \mathrm{mM}$. The values of $k_{\mathrm{cat}}$ and
$K_{\mathrm{m}}$ for the Sigma subtilisin BPN' are 642 $\mathrm{s}^{-i}$ and $0.255 \mathrm{mM}$ respectively. This enzyme is obviously not subtilisin $\mathrm{BPN}^{\prime}$. The commercial subtilisin Carlsberg from Sigma (Protease Type VIII, P 5380) has similar properties to the commercial subtilisin $\mathrm{BPN}^{\prime}: k_{\text {cit }}$ is $938 \mathrm{~s}^{-1}$ and $K_{\mathrm{m}}$ is 0.234 $\mathrm{mM}$. We also find that the $p K_{\mathrm{a}}$ of the active site of the commercial sample of $\mathrm{BPN}^{\prime}$ is identical to that of the Carlsberg enzyme and different from the value found for both the authentic and cloned samples ${ }^{3}$. Sigma have now performed amino-acid analyses and isoelectic point determinations and find that they are inconsistent with their enzyme being subtilisin BPN'.

It has just been reported that subtilisin BPN' obtained through Serva has the same sequence and crystal structure as subtilisin Carlsberg (the sequence of genuine $\mathrm{BPN}^{\prime}$ being about $70 \%$ homologous to Carlsberg). It is likely that further preparations of subtilisin BPN' $^{\prime}$ marketed by other suppliers are similarly dubious, not least because subtilisin BPN' from Sigma is prepared for Sigma and not by them. Subtilisin BPN' is also supplied to the food industry and so such users may now wish to check that they are using the correct enzyme.

Much of the work which has been performed on commercial subtilisin $\mathrm{BPN}^{\prime}$ over the past ten years must be revaluated in light of the above, especially those studies comparing commercial subtilisins BPN' and Carlsberg ${ }^{6}$.

We thank Sigma for their concern and help in resolving the problem.

Alan J. Russell Alan R. FERSHT

Department of Chemistry,

Imperial College of Science

and Technology,

South Kensington,

London SW7 $2 A Y, U K$

1. Wells. J.A. et al. Nucleic Acids Res. 11. $7911-7925$ (1983) Vasantha. N. et al. J. Bact. 160.811-819 (1984).

Thomas. P.G.. Russell. A.J. \& Fersht. A.R. Nature 318 375-376 (1985).

4. Wright, C.S. Alden. R.A. \& Kraut. J. Nature 221. 235 (1969)

Bode. W. et al. EMBO J. 5.813-818(1986)

6. Jordan, F., Polgar. L. \& Tous, G. Biochemistry 24. 7711. 7717 (1985).

\section{Alu sequences in the LDL receptor messenger RNA}

SIR-Alu-like sequences, which are highly conserved in eukaryotes, are found, for instance, in the signal recognition particle $^{1.2}$ where, in conjunction with a $9 / 14 \mathrm{~K}$ protein they arrest the synthesis of presecretory proteins at the level of elongation according to the recent work of Siegel and Walter'. At the end of their paper, Siegel and Walter made an interesting suggestion about the possible function of the $A l u$ sequences in the mRNA of the 